\title{
Phyllis Jean McAlpine, Ph.D, FCCMG
}

\section{2-1998}

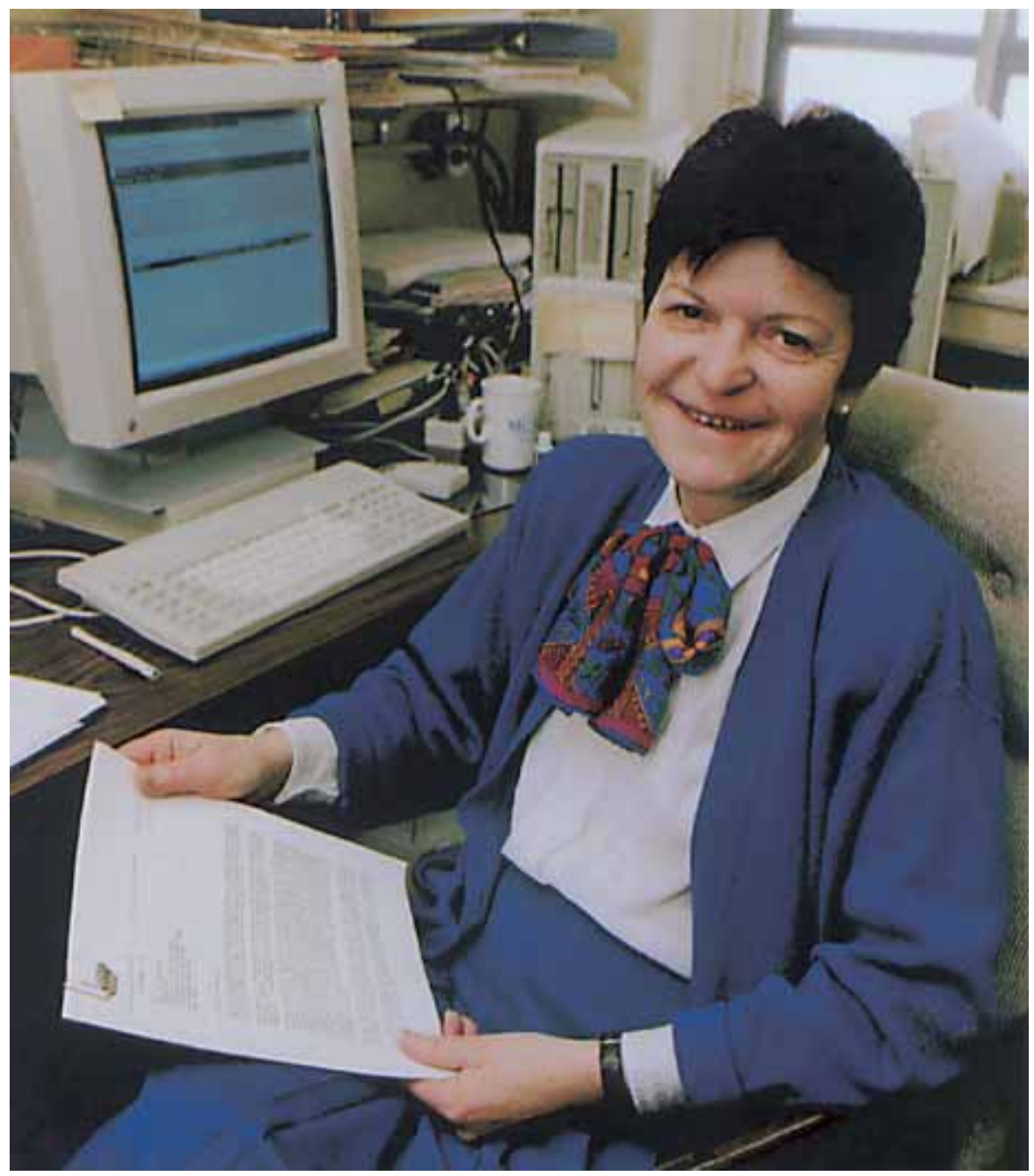

Many in the genetics community have lost a good friend and colleague. Phyllis Jean McAlpine was born in Southern Ontario where she received her early education. She graduated with a B.Sc.(Honours) degree from the University of Western Ontario, and won the Gold Medal in Zoology. She was interested in biology, but as circumstances evolved, she registered as a graduate student in genetics with Dr. Margaret Thompson as supervisor. She obtained her M.A. from University of Toronto, in Human Genetics, in muscular dystrophy research. She then moved to England and obtained a Ph.D. in Human Genetics from University 
College, London, working under the supervision of Professor Harry Harris in the Galton Lab, one of the premier biochemical genetics laboratories of the day. Following this, she did three years of post-doctoral training in London, England and at Queen's University, Kingston, Ontario. During her post-doctoral experience with Dr. Nancy Simpson in Kingston, she worked on allele frequencies in a Canadian 'Eskimo' population as part of the International Biological Program on circumpolar populations. This required her to make several visits to the DEW (Distant Early Warning) line in the Canadian north to collect blood samples for genetic analysis. She was appointed as research associate in the Section of Genetics, Department of Paediatrics and Child Health, University of Manitoba, Winnipeg in 1972, and remained a member of the Faculty of Medicine at the University of Manitoba for the rest of her life.

In Winnipeg she immersed herself with mapping of human genes before it had become a fashionable exercise. She was the first to regionally assign a human gene to a specific chromosome region. She is probably best known for her work on human gene nomenclature serving as chair or co-chair of the Human Gene Mapping Workshops from 1977 until 1991. From 1992 until 1996 and as an executive member, she chaired the committee on nomenclature for the annual Human Gene Mapping Chromosome Coordinating meetings. Phyllis was widely recognized as a world leader in this area. Her legacy is the order that presently exists in the complex field of nomenclature of human genes and DNA segments. Following her resignation from this position in 1996 due to failing health, the 1997 meeting of the International Nomenclature Workshop was dedicated in her honour. She published nearly 100 original scientific papers, and numerous abstracts. She held dozens of research grants from local and national agencies, and was funded by the Medical Research Council of Canada for most of her career. She served on the editorial boards of several international journals including Cytogenetics and Cell Genetics.

Phyllis attained the rank of full Professor in 1985. Following Professor John Hamerton's "retirement" in 1993, she was appointed head of the Department of Human Genetics, an appointment which was renewed in 1998. She was a member of the University Senate from 1981-1985 and served on the Senate Executive Committee and several Senate committees. She served as Chair of the University Discipline Committee from 1990 to 1994. She was quick to grasp the importance of basic discoveries in genetics, and their integration into the clinical arena. She was a good teacher, and was always keen to teach undergraduate medical students and residents, and the several graduate students whom she supervised. She was an advocate for women in academic circles, especially for those in the sciences. She served as President of the Canadian Association of Women in Science, Manitoba Chapter, from 1993 to 1994. She was active in many other community activities, having served as an executive member of her church board, and as President of the Manitoba Opera Guild from 1976 to 1978.

Her work in the Canadian genetics community was widely recognized. She was President of the Genetics Society of Canada (1995-1996) and a Fellow of the Canadian College of Medical Geneticists, serving as Vice-President from 1986-1988. She was elected a Fellow of the American Association for the Advancement of Science in 1996. Prior to her death, the Canadian College of Medical Geneticists awarded her with its Founders Award, in recognition of her outstanding achievement and exceptional commitment to medical genetics in Canada and worldwide.

Phyllis McAlpine was an exemplary academic who made important contributions to the wellbeing of the University of Manitoba and to her chosen profession. Those who were close to Phyllis will miss her hearty laughter, her warm broad smile, and her devoted friendship. She will be deeply missed by her mother, brother, sister and brother-in-law, nieces, nephews and her many colleagues and friends, within the University of Manitoba and worldwide.

John L. Hamerton Albert E. Chudley University of Manitoba 